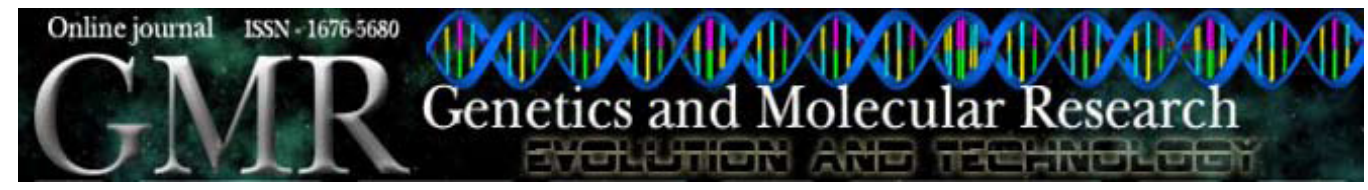

\title{
Investigating paraoxonase-1 gene Q192R and L55M polymorphism in patients with renal cell cancer
}

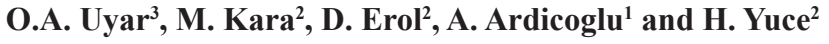 \\ ${ }^{1}$ Department of Urology, School of Medicine, Firat University Elazig, Turkey \\ ${ }^{2}$ Department of Medical Genetics, School of Medicine, Firat University, \\ Elazig, Turkey \\ ${ }^{3}$ Department of Urology, Elazig State Hospital, Elazig, Turkey \\ Corresponding author: M. Kara \\ E-mail: drmuratkara@hotmail.com
}

Genet. Mol. Res. 10 (1): 133-139 (2011)

Received May 20, 2010

Accepted October 1, 2010

Published February 1, 2011

DOI 10.4238/vol10-1gmr927

\begin{abstract}
Increased oxidative stress can help promote carcinogenesis, including development of renal cell carcinoma. The enzyme protects low-density lipoproteins from oxidation and can be a factor in this process. PON1 Q192R and L55M paraoxonase gene polymorphisms were assessed in 60 renal cell carcinoma patients and 60 healthy controls. Genotypes were examined by PCR; the restriction enzyme $A l w \mathrm{I}$ was used to examine the Q192R polymorphism and Hsp92II for the L55M polymorphism. Significant differences in the PON1 Q192R polymorphism were found between patients and controls. The $\mathrm{Q}$ allele was more frequent in the patient group than in controls, while the $\mathrm{R}$ allele was more frequent in the control group. No significant differences were found in the L55M polymorphism. Additionally, there were no significant differences in $\mathrm{L}$ and $\mathrm{M}$ allele frequencies. We conclude that the $\mathrm{R}$ allele may protect against renal cell carcinoma.
\end{abstract}

Key words: Renal cell carcinoma; Q192R polymorphism; Paraoxonase; L55M polymorphism 


\section{INTRODUCTION}

Renal cell cancer (RCC) constitutes $3 \%$ of all adult tumors and is the third most common urologic cancer. In general, 8.7 new cases are reported in 100,000 individuals. The male/female ratio is $3 / 2$ (Landis et al., 1999). It usually occurs in elderly people mostly within the 6th and 7th decades (Chow et al., 1999). Most RCC are unifocal and unilateral. Bilateral involvement may be simultaneous or at different times. The rate of bilateral involvement varies from 2 to $4 \%$, and it is more frequent in familial forms. Multicentricity occurs in 10 to $20 \%$ of all patients and it is more frequent in papillary histology and familial RCC (Whang et al., 1995; Campbell, 1997). Clear cell or conventional RCC constitutes $70-80 \%$ of all tumors and they are highly vascularized (Storkel et al., 1997; Clifford et al., 1998).

Paraoxonase-1 (PON1) is a serum esterase, which is synthesized in the liver. In humans there are three different PON genes (PON1, PON2, and PON3), closely located. It is reported that PON genes are located in the q21.3 region of the long arm of chromosome 7 (Connolly et al., 2003). PON1 and PON3 are found in the liver and plasma, whereas PON2 is found especially in the endothelial layer of liver, kidney, heart, brain, and testicular tissues. It is also shown to be present in aortic smooth cells (Hassett et al., 1991). The most widely known protective effect of PON1 is the ability to hydrolyze organophosphate neurotoxins, aromatic carboxylic acid esters and insecticides. The second biological function of PON1 is its antioxidant activity. Serum PON1 is found in plasma together with HDL and it plays important role in preventing the oxidation of plasma lipoproteins (Mackness et al., 1991; Bonnefont-Rousselot et al., 1999).

Epidemiologic and molecular studies showed that there are two important genetic polymorphisms at positions 55 and 192 of the PON1 gene. These two polymorphisms arise from the substitution of amino acids at positions 55 and 192. Substitution of glutamine (Q genotype) at position 192 of the PON gene by arginine (R genotype) leads to the first polymorphism (Q192R). Similarly, substitution of leucine (L genotype) at position 55 by methionine (M genotype) leads to the second polymorphism (L55M). The most common one is homozygous QQ, the second is heterozygous QR, and the least is homozygous RR. Paraoxonase hydrolyzing activity of the protein encoded by R is 8-fold more than that encoded by the Q allele. This polymorphism also affects serum protein concentration. Homozygous RR individuals have higher enzyme concentrations than do homozygous QQ individuals (Mackness et al., 1997; Azarsiz and Sonmez, 2000). In addition to polymorphisms of these positions, five polymorphisms were reported at the PON1 promoter region. Due to these genetic polymorphisms, PON1 activity may show differences of up to 10- to 40 -fold among different individuals and populations (Playfer et al., 1976; Durrington et al., 2001).

In a study conducted in prostate cancer patients, PON192/QR and PON55LM/ $\mathrm{MM}$ genotypes were found to be related to increased risk of prostate cancer (Antognelli et al., 2005). However, in another study, PON1 Q192R and L55M polymorphisms were evaluated and no differences or relationships were found (Van Der Logt et al., 2005). We are not aware of any study in the literature that demonstrates a relationship between RCC and PON. Therefore, in this study, we investigated the PON1 Q192R and L55M gene polymorphisms in patients with RCC. 


\section{MATERIAL AND METHODS}

\section{Patient selection}

After obtaining approval of the Firat University Ethics Committee, 60 patients with clear cell carcinoma of the kidney (RCC classic type) and 60 healthy control subjects were included in the study. Written informed consent was obtained from patients and controls after explanation of study details. After a 20 -min rest, $2 \mathrm{~mL}$ blood samples were collected from the antecubital vein into tubes prepared with EDTA. All blood samples were stored at $-20^{\circ} \mathrm{C}$ until DNA purification.

\section{Methods}

\section{Determination of the PON1 192 gene polymorphism}

Polymerase chain reaction (PCR) $(25 \mu \mathrm{L})$ for the PON1 192 gene polymorphism was performed in $10 \mathrm{mM}$ Tris- $\mathrm{HCl}, \mathrm{pH} 8.4,50 \mathrm{mM} \mathrm{KCl}, 1.5 \mathrm{mM} \mathrm{MgCl}_{2}, 200 \mu \mathrm{M}$ dNTPs, 20 pmol of each primer (Biobasic, Ontario, Canada), and $1 \mathrm{U}$ Taq polymerase (Fermentas, Inc.) in a thermocycler under the following conditions: $94^{\circ} \mathrm{C}$ for 5 min (initial denaturation) followed by 35 cycles of $95^{\circ} \mathrm{C}$ for $1 \mathrm{~min}$ (denaturation), $60^{\circ} \mathrm{C}$ for $1 \mathrm{~min}$ (annealing), $72^{\circ} \mathrm{C}$ for $1 \mathrm{~min}$ (extension), and a final extension of $72^{\circ} \mathrm{C}$ for $10 \mathrm{~min}$. A 99bp fragment was amplified from $10 \mathrm{ng}$ genomic DNA. PCR products were restricted using $A l w I$ restriction endonuclease and separated by $2 \%$ agarose gel electrophoresis. PCR products of $99 \mathrm{bp}$ were digested with $2 \mathrm{U}$ AlwI (MBI Fermentas, Lithuania) at $55^{\circ} \mathrm{C}$ for $20 \mathrm{~h}$, and resulted in 99-, 69- and 30-bp fragments for the QR genotype, 69- and 30-bp fragments for the RR genotype and a non-digested 99-bp fragment for the QQ genotype. Digested products were resolved by gel electrophoresis (2\% agarose gel) and visualized by ethidium bromide staining.

\section{Determination of the PON1 55 gene polymorphism}

In genomic DNA samples of individuals, alleles of the PON1 55 locus were amplified by PCR. PCR $(25 \mu \mathrm{L})$ was performed in $10 \mathrm{mM}$ Tris- $\mathrm{HCl}, \mathrm{pH} 8.4,50 \mathrm{mM}$ $\mathrm{KCl}, 1.5 \mathrm{mM} \mathrm{MgCl}, 200 \mu \mathrm{M}$ dNTPs, $20 \mathrm{pmol}$ of each primer (Biobasic), and $1 \mathrm{U}$ Taq polymerase (Fermentas, Inc.) in a thermocycler under the following conditions: $94^{\circ} \mathrm{C}$ for $2 \mathrm{~min}$ (initial denaturation) followed by 35 cycles of $94^{\circ} \mathrm{C}$ for 1 min (denaturation), $60^{\circ} \mathrm{C}$ for $1 \mathrm{~min}$ (annealing), $72^{\circ} \mathrm{C}$ for $1 \mathrm{~min}$ (extension), and a final extension of $72^{\circ} \mathrm{C}$ for 10 min. A 170-bp fragment was amplified from $10 \mathrm{ng}$ genomic DNA. A fragment belonging to the PON1 55 locus, after PCR amplification, was restricted using Hsp92II (Promega, USA) restriction endonuclease and separated 2\% agarose gel electrophoresis. PCR products ( $170 \mathrm{bp}$ ) were digested with $2 \mathrm{U} H s p 92 \mathrm{II}$ at $37^{\circ} \mathrm{C}$ for $20 \mathrm{~h}$, and resulted in 170-, 126- and 44-bp fragments for the ML genotype, 126- and 44-bp fragments for the MM genotype and a non-digested 170-bp fragment for the LL genotype. Digested products were resolved by gel electrophoresis ( $2 \%$ agarose gel) and visualized by ethidium bromide staining. 


\section{Statistical analysis}

Concordance of genetic distribution with Hardy-Weinberg equilibrium was tested by the $\chi^{2}$ goodness-of-fit test. Differences between genotype distributions of patients and controls were evaluated using the chi-square test. Allele distribution differences of controls and patients were evaluated by the Fisher exact test. $\mathrm{P}<0.05$ was considered to be statistically significant. All statistical tests were performed using SPSS $^{\circledR}$ for Windows, version 12.0.

\section{RESULTS}

Sixty clear cell RCC patients and 60 controls were included in the study. The ages of patients varied between 32 and 82 years, with a mean age of 58 years. Only one patient had bilateral clear cell RCC. Demographic characteristics of patient and control groups are given in Table 1. All patients evaluated were classified according to the TNM system. Stage I-II patients were grouped as early stage, whereas stage III and IV patients were grouped as advanced stage (Table 2).

Table 1. Demographic characteristics of patient and control groups.

\begin{tabular}{lcc}
\hline & RCC classic type $(\mathrm{N}=60)$ & Control $(\mathrm{N}=60)$ \\
\hline Age $($ mean $\pm \mathrm{SD})$ & $60.42 \pm 12.8$ & $58.96 \pm 11.71$ \\
Gender (male/female) & $38 / 22$ & $36 / 24$ \\
\hline
\end{tabular}

$\mathrm{RCC}=$ renal cell carcinoma.

Table 2. Classification of patients according to the TNM system.

\begin{tabular}{lccccc}
\hline & \multicolumn{3}{c}{ Early stage } & & \multicolumn{2}{c}{ Advanced stage } \\
\cline { 2 - 4 } & I & II & III & IV \\
\hline Patients $[\mathrm{N}(\%)]$ & $24(40.0 \%)$ & $14(23.3 \%)$ & $12(16.6 \%)$ & $10(20,0 \%)$ \\
\hline
\end{tabular}

$\mathrm{TNM}=$ primary tumor $(\mathrm{T})$, regional nodes $(\mathrm{N})$, and metastases $(\mathrm{M})$.

Genotype distributions of classic type RCC patients and controls and Q and R allele distributions are summarized as numbers and percentages in Table 3. At the end of our study, the PON1 gene Q192R polymorphism genotype distribution was obtained. According to our results, the QQ genotype was the most common (38; 63.3\%) in the patient group, and the QR genotype was the second most common type $(21 ; 35.5 \%)$. The RR genotype was found in only one subject in the patient group while it was present in 6 subjects in the control group. Statistical analysis demonstrated a significant difference between genotype distributions $(\mathrm{P}=0.045)$. In addition, when the RCC group was compared to the control group with respect to $\mathrm{Q}$ and $\mathrm{R}$ allele frequencies, there were statistically significant differences between the patient and control groups $(\mathrm{P}=0.013)$. The $\mathrm{Q}$ allele frequency was higher in the patient group than in the control group, whereas the R allele frequency was higher in the control group. LL, LM, and MM genotype numbers and percentages obtained for the PON1 gene L55M polymorphism and L and $\mathrm{M}$ allele distributions are summarized in Table 4. In our study of the PON1 gene L55M 
polymorphism, the LL genotype was found in 29 (48.3\%) patients, whereas the LM genotype was found in $25(41.7 \%)$ patients. The MM genotype was present in $6(10.0 \%)$ patients. In the control group, LL, LM and MM genotypes were found in 21 (35.0\%), 29 (48.3\%), and $10(16.7 \%)$ subjects, respectively. There was no statistically significant difference between patient and control groups in terms of the PON1 gene L55M polymorphism $(\mathrm{P}=0.276)$. In the patient group, the $\mathrm{L}$ allele frequency was $83(69.2 \%)$ and the $\mathrm{M}$ allele frequency was 37 (30.8\%). On the other hand, in the control group, the L allele frequency was $71(59.2 \%)$ and the $\mathrm{M}$ allele frequency was $49(40.8 \%)$. Allele distributions were different but this difference did not reach statistical significance $(\mathrm{P}=0.069)$.

Table 3. PON1 Q192R genotype distribution of classic type renal cell carcinoma (RCC) patients and the control group.

\begin{tabular}{lccccc}
\hline & QQ & QR & RR & Q allele distribution & R allele distribution \\
\hline RCC patients $(\mathrm{N}=60)$ & $38(63.3 \%)$ & $21(35.5 \%)$ & $1(1.7 \%)$ & $97(80.8 \%)$ & $23(19.2 \%)$ \\
Controls $(\mathrm{N}=60)$ & $27(45.0 \%)$ & $27(45.0 \%)$ & $6(10.0 \%)$ & $81(67.5 \%)$ & $39(32.5 \%)$ \\
\hline
\end{tabular}

Data are reported as number with percent in parentheses.

Table 4. PON1 L55M genotype distribution of classic type renal cell carcinoma (RCC) patients and the control group.

\begin{tabular}{lccccc}
\hline & LL & LM & MM & L allele distribution & M allele distribution \\
\hline RCC patients $(\mathrm{N}=60)$ & $29(48.3 \%)$ & $25(41.7 \%)$ & $6(10.0 \%)$ & $83(69.2 \%)$ & $37(30.8 \%)$ \\
Controls $(\mathrm{N}=60)$ & $21(35.0 \%)$ & $29(48.3 \%)$ & $10(16.7 \%)$ & $71(59.2 \%)$ & $49(40.8 \%)$ \\
\hline
\end{tabular}

Data are reported as number with percent in parentheses.

\section{DISCUSSION}

Although the etiology of renal cell carcinoma is not yet clear, oxidative stress is considered to be a factor in the development of RCC as in the other cancer types. In a study of antioxidant enzymes in RCC, catalase and selenium-dependent or selenium-independent glutathione peroxidase enzymes were shown to be low (Pljesa-Ercegovac et al., 2008). Another study showed that cytoplasmic superoxide dismutase and glutathione peroxidase activities were lower in RCC tissues than in normal tissues (Lusini et al., 2001). Furthermore, there are several reports suggesting a relationship between RCC and lipid peroxidation (Gago-Dominguez et al., 2002; Gago-Dominguez and Castelao, 2006).

Synthesized in human liver, PON1 is a serum esterase, which has the ability to hydrolyze paraoxone, the active metabolite of parathione. Human serum PON1 is bound physically to HDL (Mackness et al., 1996; Primo-Parmo et al., 1996). The physiological role of PON1 is not fully understood, but it protects LDL from oxidation via hydrolyzing lipid peroxides. In addition, it has some protective effects against cellular damage resulting from toxic agents such as organophosphates (Mackness et al., 1996).

As paraoxonase has antioxidant effects, such as in preventing LDL oxidation, it is considered that it may have role in the pathogenesis of many disorders related to oxidative stress. Nevertheless, the relationship between serum PON1 levels and cancer is not fully known. 
However, Akcay et al. (2003a) investigated the relationship of PON1 and plasma lipoproteins in pancreatic and gastric cancer patients. They compared 20 patients with pancreatic cancer and age- and gender-matched 20 healthy controls, and showed that HDL and PON1 levels were significantly lower in patients with pancreatic cancer than in the control group. In another study, Akcay et al. (2003b) obtained similar results when comparing gastric cancer patients with a control group. When we combine the results of these two studies in pancreatic and gastric cancer patients, we can say that HDL and PON1 levels are lower in cancer patients than in control subjects (Akcay et al., 2003a,b). In addition, PON activity was investigated in patients with lung cancer, and enzyme activities were found to be significantly lower in lung cancer patients (Elkiran et al., 2007). All these studies suggest that PON1 enzyme may protect against cancer with its antioxidant effects. However, we are not aware of a study in the literature, investigating the relationship between RCC and paraoxonase.

Some alterations in paraoxonase activity were reported with these polymorphisms. Mackness et al. (1997) in their study showed important alterations in the activity of paraoxonase due to these two polymorphisms. As a result of this study, the QQ genotype was found to be the lowest, the QR genotype had a moderate activity, and the RR genotype had the highest enzyme activity. Similarly, when the MM homozygous genotype was compared to ML and LL genotypes, lower enzyme activities were demonstrated. The lowest enzyme activities were found in QQ and MM genotypes (Mackness et al., 1997). After the discovery of the ability of these polymorphisms to alter enzyme activity, it has been considered that there may be a correlation between these polymorphisms and cancer; furthermore, certain genotypes may lead to a tendency toward the development of cancer. In a polymorphism study of prostate cancer, a relationship was shown between PON1 192/QR and PON1 55LM/MM genotypes and the risk of prostate cancer (Antognelli et al., 2005). On the other hand, in a similar study, the authors failed to demonstrate a relationship between PON1 Q192R and L55M polymorphisms and colon cancer (Van Der Logt et al., 2005).

However, there were some limitations in our study. First, only 60 clear cell RCC patients and 60 controls were included in the study. Second, it would also be very interesting to see the distribution of the PON1 polymorphism in different stages. Third, PON1 activity is more important because of its potential function in renal cell cancer, so PON1 activity could be measured in the serum of patients and controls to see if there is any relationship between different stages or any difference between patients and the control group.

According to our results, there is no relationship between the L55M polymorphism and RCC. However, some studies in the literature reported that the L55M polymorphism may change enzyme activity as in the Q192R polymorphism (Mackness et al., 1997). From this point of view, there may be differences between subgroups in this polymorphism. In our study, the patient group was limited in number and this might have led to a lack of differences. The same polymorphisms should be studied in a larger patient group. In this study, we demonstrated that there was a difference between the RCC and control groups in terms of the PON1 Q192R polymorphism, and that in the patient group, the Q allele was more frequent whereas the $\mathrm{R}$ allele was less frequent than in the control group. Conversely, the $\mathrm{R}$ allele frequency was higher in the control group. All these findings suggest that the R allele is protective against RCC. However, these findings should be supported by further studies of enzyme activities with these polymorphisms in a larger patient group, which would better clarify the relationship between PON1 and RCC. 


\section{REFERENCES}

Akcay MN, Polat MF, Yilmaz I and Akcay G (2003a). Serum paraoxonase levels in pancreatic cancer. Hepatogastroenterology 50 (Suppl 2): CCXXV-CCXXVII.

Akcay MN, Yilmaz I, Polat MF and Akcay G (2003b). Serum paraoxonase levels in gastric cancer. Hepatogastroenterology 50 (Suppl 2): CCLXXIII-CCLXXV.

Antognelli C, Mearini L, Talesa VN, Giannantoni A, et al. (2005). Association of CYP17, GSTP1, and PON1 polymorphisms with the risk of prostate cancer. Prostate 63: 240-251.

Azarsiz E and Sonmez EY (2000). Paraoxonase and clinical importance. Turk. J. Biochem. 25: 109-119.

Bonnefont-Rousselot D, Therond P, Beaudeux JL, Peynet J, et al. (1999). High density lipoproteins (HDL) and the oxidative hypothesis of atherosclerosis. Clin. Chem. Lab. Med. 37: 939-948.

Campbell SC (1997). Advances in angiogenesis research: relevance to urological oncology. J. Urol. 158: 1663-1674.

Chow WH, Devesa SS, Warren JL and Fraumeni JF Jr (1999). Rising incidence of renal cell cancer in the United States. JAMA 281: 1628-1631.

Clifford SC, Prowse AH, Affara NA, Buys CH, et al. (1998). Inactivation of the von Hippel-Lindau (VHL) tumour suppressor gene and allelic losses at chromosome arm $3 \mathrm{p}$ in primary renal cell carcinoma: evidence for a VHLindependent pathway in clear cell renal tumourigenesis. Genes Chromosomes Cancer 22: 200-209.

Connolly JL, Schnitt SJ, Wang HH, Longtine JA, et al. (2003). Principles of Cancer Pathology. In: Cancer Medicine (Kufe DW, Pollock RE and Weichselbaum RR, eds.). Hamilton-BC Decker, London, 487-502.

Durrington PN, Mackness B and Mackness MI (2001). Paraoxonase and atherosclerosis. Arterioscler. Thromb. Vasc. Biol. 21: $473-480$.

Elkiran ET, Mar N, Aygen B, Gursu F, et al. (2007). Serum paraoxonase and arylesterase activities in patients with lung cancer in a Turkish population. BMC Cancer 7: 48.

Gago-Dominguez M and Castelao JE (2006). Lipid peroxidation and renal cell carcinoma: further supportive evidence and new mechanistic insights. Free Radic. Biol. Med. 40: 721-733.

Gago-Dominguez M, Castelao JE, Yuan JM, Ross RK, et al. (2002). Lipid peroxidation: a novel and unifying concept of the etiology of renal cell carcinoma (United States). Cancer Causes Control 13: 287-293.

Hassett C, Richter RJ, Humbert R, Chapline C, et al. (1991). Characterization of cDNA clones encoding rabbit and human serum paraoxonase: the mature protein retains its signal sequence. Biochemistry 30: 10141-10149.

Landis SH, Murray T, Bolden S and Wingo PA (1999). Cancer statistics. CA Cancer J. Clin. 49: 8-31.

Lusini L, Tripodi SA, Rossi R, Giannerini F, et al. (2001). Altered glutathione anti-oxidant metabolism during tumor progression in human renal-cell carcinoma. Int. J. Cancer 91: 55-59.

Mackness B, Mackness MI, Arrol S, Turkie W, et al. (1997). Effect of the molecular polymorphisms of human paraoxonase (PON1) on the rate of hydrolysis of paraoxon. Br. J. Pharmacol. 122: 265-268.

Mackness MI, Arrol S and Durrington PN (1991). Paraoxonase prevents accumulation of lipoperoxides in low-density lipoprotein. FEBS Lett. 286: 152-154.

Mackness MI, Mackness B, Durrington PN, Connelly PW, et al. (1996). Paraoxonase: biochemistry, genetics and relationship to plasma lipoproteins. Curr. Opin. Lipidol. 7: 69-76.

Playfer JR, Eze LC, Bullen MF and Evans DA (1976). Genetic polymorphism and interethnic variability of plasma paroxonase activity. J. Med. Genet. 13: 337-342.

Pljesa-Ercegovac M, Mimic-Oka J, Dragicevic D, Savic-Radojevic A, et al. (2008). Altered antioxidant capacity in human renal cell carcinoma: role of glutathione associated enzymes. Urol. Oncol. 26: 175-181.

Primo-Parmo SL, Sorenson RC, Teiber J and La Du BN (1996). The human serum paraoxonase/arylesterase gene (PON1) is one member of a multigene family. Genomics 33: 498-507.

Storkel S, Eble JN, Adlakha K, Amin M, et al. (1997). Classification of renal cell carcinoma: Workgroup No. 1. Union Internationale Contre le Cancer (UICC) and the American Joint Committee on Cancer (AJCC). Cancer 80: 987-989.

Van Der Logt EM, Janssen CH, Van Hooijdonk Z, Roelofs HM, et al. (2005). No association between genetic polymorphisms in NAD(P)H oxidase p22phox and paraoxonase 1 and colorectal cancer risk. Anticancer Res. 25: 1465-1470.

Whang M, O’Toole K, Bixon R, Brunetti J, et al. (1995). The incidence of multifocal renal cell carcinoma in patients who are candidates for partial nephrectomy. J. Urol. 154: 968-970. 